\title{
Moisture safety in CLT construction without weather protection - Case studies, literature review and interviews
}

\author{
Lars Olsson ${ }^{1}$ \\ ${ }^{1}$ RISE Research Institutes of Sweden, Division Build Environment, Building Technology, Sweden
}

\begin{abstract}
This project aims to expand understanding of how cross-laminated timber (CLT) constructions, including joints, connections and attachment points, are impacted by precipitation during construction. The project's case studies have been based on measurements of moisture contents and material sampling as well as microbiological analysis during the construction stage of the structure. The study does not include control of remediation. A literature review and interviews with seven individuals also were conducted. The results are based on two case studies with a total of four buildings. The field measurements show microbiological growth in all buildings and essentially on all investigated floor structures. Of a total of 200 analysed measuring points, half had some growth and about a third had moderate or extensive growth. Based on the outcome, it seems difficult or impossible to avoid the appearance of microbial growth during construction with CLT without weather protection. The literature review shows that microbiological analysis of CLT is extremely rare in both laboratory and field studies, which indicates that there are obvious shortcomings in the scientific work in practical studies. However, there seems to be good awareness in the literature that theoretical studies often conduct mould growth risk evaluations. In the survey, half of those interviewed believed that remediation was needed only in the case of growth visible to the naked eye. There appear to be no moisture safety assembly methods or solutions for CLT construction without weather protection or declaration of the critical moisture conditions for CLT products. As a result, it is recommended that weather protection is used, preferably complete weather protection.
\end{abstract}

\section{Introduction}

\subsection{Background}

There are many advantages of wood as a building material. High bearing capacity with low dead weight, flexible solutions with high prefabrication levels and fast building processes, relatively good insulating properties in relation to many other framing materials, financial advantages and environmental advantages are some of the explanations for the increased use of wood in larger buildings. The building industry's major focus on resource efficiency means an increase in timber construction, particularly the large increase of building in modules of cross-laminated timber. Many modules are purchased from other countries in Europe where the use of weather protection is non-existent. A new phenomenon for Sweden in large-scale timber construction is timber building suppliers that have partially adopted European building methods and building without weather protection, see Figure 1, in the form of tents and instead attempting to minimise weather impacts and aiming to manage to dry up before moisture-related problems occur. There is a belief in the industry today, even internationally, that CLT's dense wood constitution allows moisture safety construction even when exposed to precipitation. There is, however, a lack of verified documentation for this belief.

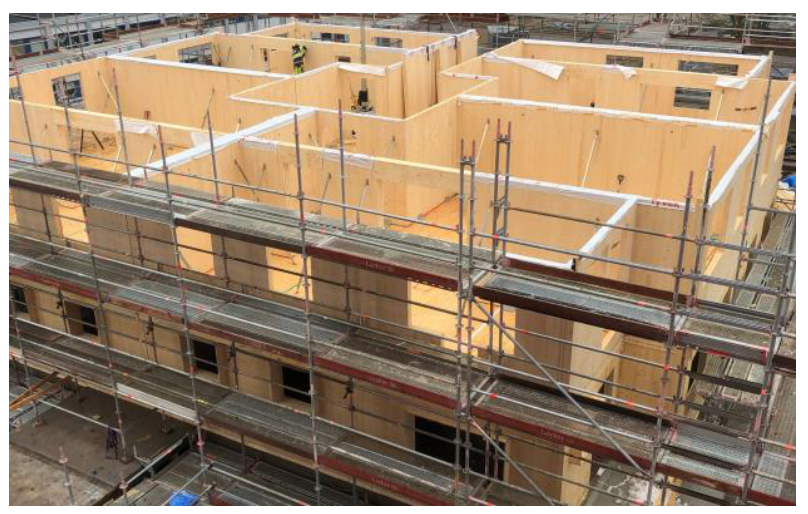

Fig. 1. Ongoing assembly of CLT frame without weather protection in central Sweden.

\subsection{Purpose}

The project aims to expand understanding of how crosslaminated timber (CLT) constructions, including joints, connections and attachment points, are impacted by precipitation during construction and how to manage moisture safety. This will enable the industry to determine weather-protection needs.

\footnotetext{
* Corresponding author: $\underline{\text { lars.olsson } @ \text {,ri.se }}$
} 


\subsection{Scope and focus}

The project involves following the construction of the structure of four seven-floor buildings located in two different areas of the country. Each building is followed up with instantaneous electric-resistance moisture measurements and sampling for microbiological analysis of solid wood structure during construction as far as practically possible within the framework of the project. The surrounding climate conditions both indoor and outdoor are followed up and the climate is assessed with mould risk simulations. The project also includes an interview study of seven individuals (site managers, project engineers and consultants) with experience of CLT constructing without weather protection. A literature review looking at moisture and mould is also conducted.

The moisture safety plans for the construction projects are documented before the start of construction and construction is then followed up with random sampling to evaluate how the plan is actually followed by moisture experts on the construction project.

The project focuses on moisture and microbial growth in CLT construction. It is aimed at solid wood building systems with assembled CLT panels assembled using mechanical attachments on site. The study does not cover completion of the building envelope, insulation and interior and exterior surfaces nor highly prefabricated construction systems where CLT panels are assembled using insulation, installations, carpentry or any complete surface layers straight in the factory. This research project has not included follow-up of remediation efforts

\section{Literature review}

\subsection{Regulations and specifications}

The Swedish Building Code makes clear demands on moisture safety [1]. The general advice is that buildings, building products and building materials should be protected from moisture and dirt during the construction period. Control that material is not damaged by moisture during the construction period should take place through documented inspections, measurements or analyses. The general material and work specifications for construction [2] require "Wood materials and wood products to be protected from moisture during and after assembly to avoid microbial growth and other problems".

\subsection{Literature review}

Moisture effects on timber have been studied previously $[3,4]$ and appropriate weather protection has been developed and studied over many years [5-7]. CLT handbooks and published national and international recommendations recommend that CLT be protected from moisture [8-10].

Mould growth on wood can begin immediately at high humidity and exposure to water at favourable temperatures $[11,12]$. "Wood is a material that easily grows mouldy and the mould can grow quickly if the conditions are favourable" [13]. A critical requirement for microbial growth is moisture, and a relative humidity over $75 \%$ or a moisture content of over $15 \%$ have been shown to be sufficient moisture levels to allow mould to grow at favourable temperatures and duration. Since wood can have different moisture contents at $75 \%$ relative humidity depending on whether the material is absorbing moisture or drying out, known as hysteresis, the critical moisture content can vary. During drying out, the critical limit is over $18 \%$ moisture content [14]. Wood sill plates and floor studs exposed to 24-hours of water and then more or less prevented from drying out immediately have a great risk of mould growth [15]. Mould growth is often invisible to the naked eye, so detection requires magnification using a microscope $[4$, 16].

A general literature review of over 30 publications on CLT has been done, $[3,8,10,17-47]$. It indicates that microbiological analysis of CLT exposed to critical moisture levels or standing water is unusual, only one practical study did microbiological analysis [30]. It seems that there is often a lack of scientific knowledge in field and laboratory studies since the consequences of critical moisture content are not examined using microbiological analysis. The result is that in those cases it is not possible to say whether mould has developed or not, except when it is visibly obvious. Several theoretical studies, however, do note the risk of mould growth based on mould risk simulations. These theoretical studies, however, rarely include the critical components that take the longest to dry. Many studies note that more research is needed on moisture in CLT.

\section{Interviews}

Interviews have been conducted with seven individuals with experience of CLT construction without weather protection. These individuals come from different companies and from different areas in southern and central Sweden. All the individuals have experience of at least one building project without weather protection and several have experience from multiple projects. Most have extensive experience from the building industry. The interviews covered such as questions as: Why is construction done without weather protection? What methods are used to reduce water exposure? What is critical moisture content? Is mould growth a problem? How is this checked? Is mould visible for the naked eye? Is unseen mould a problem? How is mould growth remediated?

A summary of the responses indicates that most feel that there is a large difference in project costs between having and not having weather protection. Although moisture safety was planned for, the construction projects these individuals were involved in took place without weather proofing, which is contradictory since this type of planning is to lead to moisture safety construction. Remediation was probably included in the planning since all those surveyed, used remediation to address moisture. About half of the individuals felt that 
only remediation is needed when there is visible growth even though all of the individuals know that mould growth can be invisible. Few knew that the National Building Regulations specify a limit [1] for critical moisture content at $75 \%$ relative humidity for materials and products that lack documentation. Everyone, however, responded that the critical moisture content was landed at $15-18 \%$ and several noted that these values may not be exceeded when the material is incorporated into the building. A common method of removing growth seems to be sanding.

\section{Case studies}

\subsection{Four buildings}

The construction of the structure for a seven-floor office building in western Sweden, Figure 2, was monitored using measurements. The building frame consists of seven floors of laminated columns and CLT floor structures. The floor structures consist of seven layers with planed timber with a total CLT thickness of 230 $\mathrm{mm}$ and the upper layer with a thickness of $40 \mathrm{~mm}$. The frame has also been braced with steel columns and steel floor beams. The CLT moisture content at delivery was $12 \%$. The frame began to be built in January 2018 and was divided into three stages where half of the building's frame, stage A, was built to floor structure five. Then the second half of the building was built, stage B, to the fifth floor. Each floor required approximately up to three weeks for assembly. Stage $\mathrm{C}$ began from the fifth floor and the roof was made watertight at the end of July 2018 .

Three seven-floor buildings in central Sweden were studied as their frames were built, see Figure 1 and 3 . The building frames consist of CLT walls and CLT floor structures. The floor structures consist of 5 layers with planed timber with a total CLT thickness of $200 \mathrm{~mm}$ and the upper layer with a thickness of $40 \mathrm{~mm}$. The exterior walls had a thickness of $200 \mathrm{~mm}$ and the interior walls were between 140 and $200 \mathrm{~mm}$ thick CLT. The CLT moisture content at delivery was also $12 \%$. The wood frame of the first building was assembled in December 2018 and the roof was watertight in the beginning of March 2019. The second building began to be assembled in January 2019 and the roof was watertight in midMarch 2019. The third building began to be assembled in March 2019 and the roof was watertight in mid-May 2019.

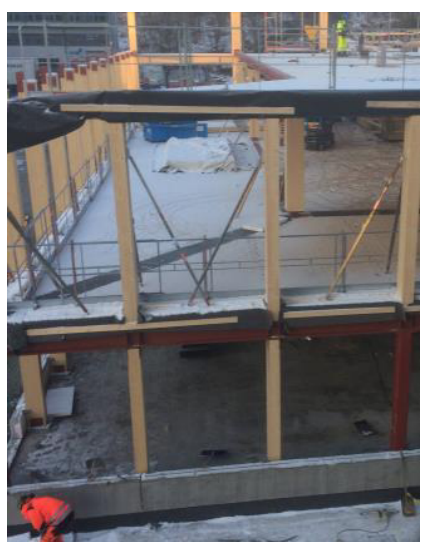

Fig. 2. Frame construction at the case study in west Sweden and snow on the floor structures. Assembly of CLT frame without weather protection.

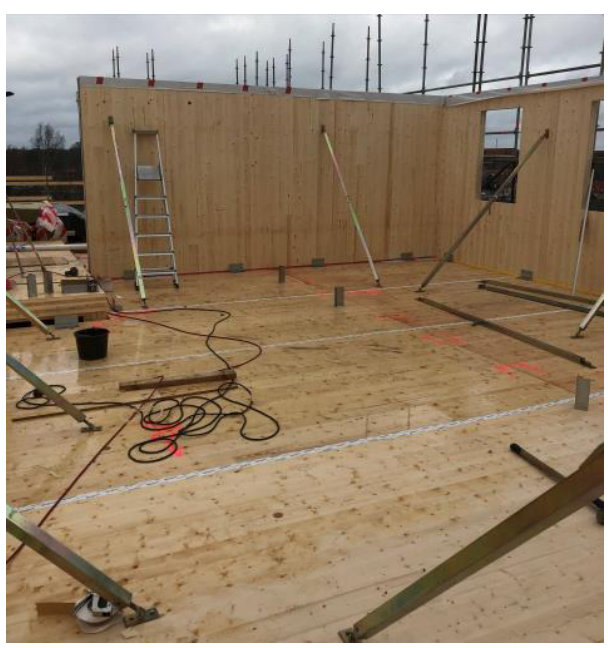

Fig. 3. Ongoing assembly with water standing on the floor structure after precipitation in central Sweden.

\subsection{Moisture safety efforts during construction}

The reason for building without weather protection is primarily financial. The projects included planning for moisture safety and a moisture specification document was produced. This work has been followed and monitored regularly by the contractor's moisture safety manager and the developer's moisture expert. Methods for attempting to limit water exposure were planned, and in cases where the consequences of moisture build up and microbial growth cannot be avoided, then these are to be remediated. Several different methods were tested, such as taping, see Figures 3 and 4, covering joints or holes with plywood boards, covering the edges of floor structures with felt paper, and separating wood columns or CLT walls from the floor structures by placing them on steel stands, plastic blocks or sound and vibration pads. Water was removed with a wet vacuum cleaner. The plan was for each floor structure to be exposed to the weather for at most 1-2 weeks and that they could be exposed to water from precipitation. 


\subsection{Could the moisture safety plan be followed?}

The CLT provider had no problem meeting the specified $12 \%$ moisture content at delivery of these projects. Moisture measurements were conducted about every other or every third week and were documented by the contractor's moisture safety manager and/or the developer's moisture expert. It proved difficult to keep the tape attached during precipitation while assembly took place and sometimes the tape fell off. It was also difficult to seal uneven surfaces and connected openings in the floor structure. The conclusion was that it was not possible to completely seal using tape. It was also difficult to ensure that the seals created with boards and plywood remained sealed. Since the leaky parts of the floor structure were located in about the same spots vertically, water was able to continue to several lower floor structures since these were also leaky at the same points, see Figures 5 and 6 .

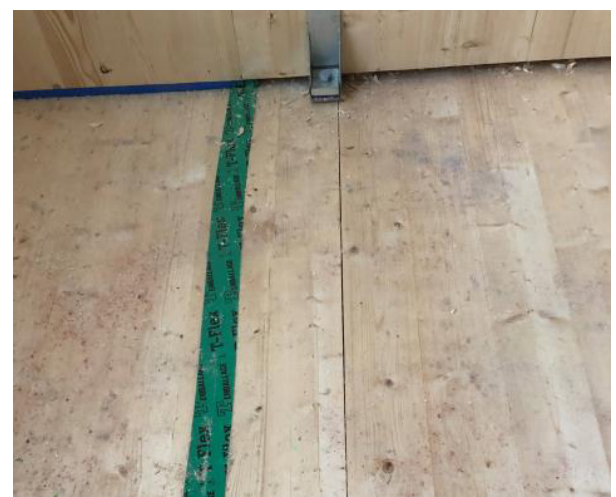

Fig. 4. Taped floor structure joints.

It proved difficult to remove water quickly and with larger leaks it was difficult to vacuum away all of the water in a timely fashion. Since most of the floor structures were exposed to water, they had a high moisture content on these surfaced until they were dried. Remediation of surfaces consisted of sanding, sawing with a circular saw in openings, and other measures, and there was more remediation work than planned. This information was provided by the moisture safety manager or the developer's moisture expert.

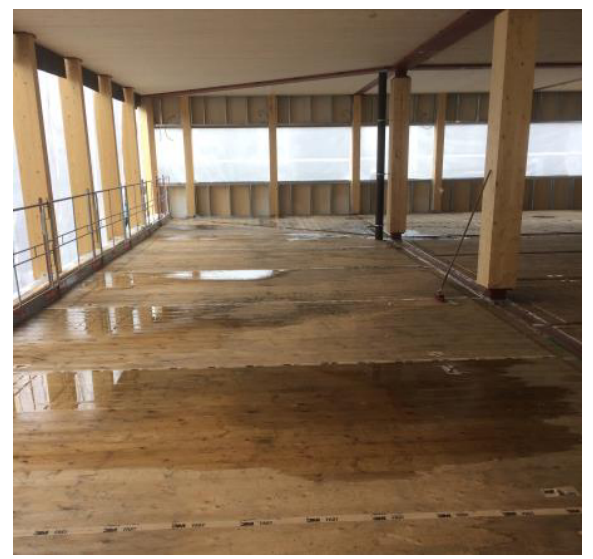

Fig. 5. On several occasions, water pooled on the floor structure. Precipitation ran down primarily from the above floor structures.

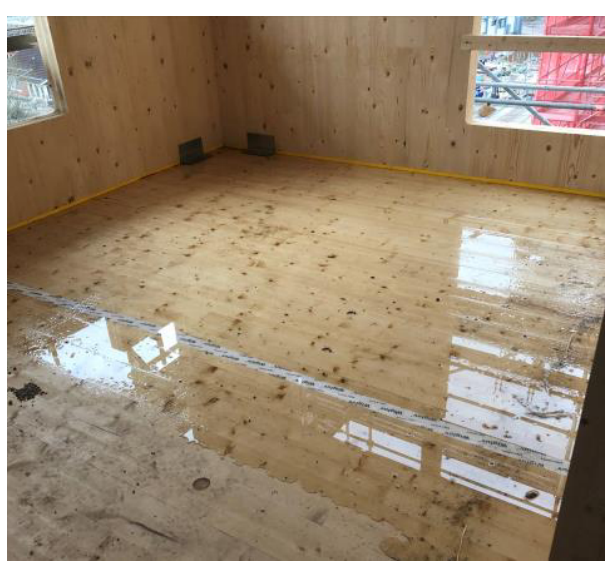

Fig. 6. Pooled water on floor structure in central Sweden. Precipitation ran down from the above floor structures.

\subsection{Ambient climate}

Data on the immediate surrounding outdoor weather conditions for the case studies in west Sweden and central Sweden were taken from nearby weather stations [48]. The weather stations were located about 10 kilometres from the buildings. Measurement data for outdoor conditions, such as relative humidity, temperature and precipitation, see for example Figure 7, were taken from the Swedish weather services' database [48].

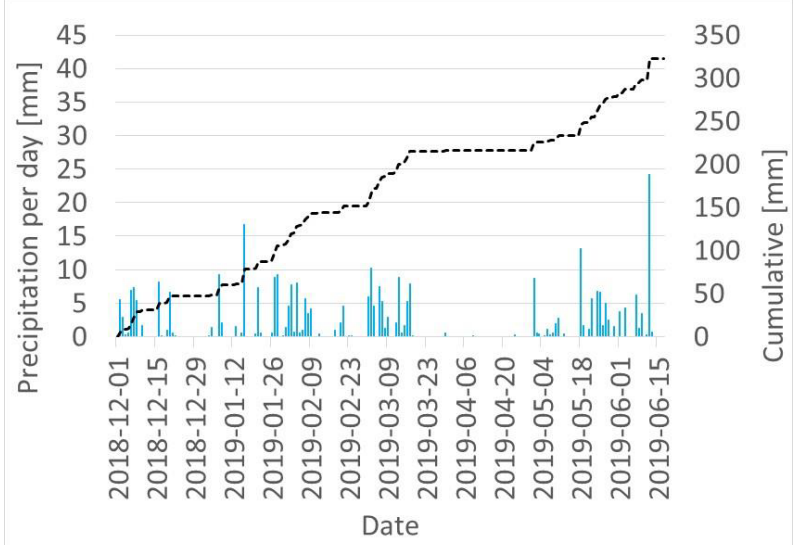

Fig. 7. Precipitation in $\mathrm{mm}$ rain per day and cumulative in $\mathrm{mm}$ rain during construction stage in central Sweden.

The indoor conditions have been followed up regularly with continual measurements of air relative humidity in the rooms and the air temperature on some of the floors where the buildings have been covered or sealed.

Measurement uncertainty for the continual measurements (Protimeter Hygrotrac) at the central Sweden site for relative humidity is estimated at $\pm 4 \%$ and $\pm 0.5{ }^{\circ} \mathrm{C}$ for the temperature. The west Sweden site used the logging system Celsicom and the sensors TH501A. The sensors were new and were calibrated at delivery. They were not calibrated at the end of the measurement period.

Evaluation of air (relative humidity and temperature) were done using mould risk simulations based on the 
mould resistance design (MRD) model [49] with a critical dose on 17 days for planed spruce in accordance with the model.

The analyses showed no risk of mould growth at all related to either the outdoor air or indoor air. On the other hand, precipitation data [48] has been analysed, see for example Figure 7, and compared with the assembly periods, see for example Table 1, and this has shown that most floor structures were exposed to precipitation during construction before floor structure above or protective roofing was installed.

Table 1. Approximate times when respective floor was installed, roofs became dense and the temporary heat supply started, at several floors in the buildings in central Sweden.

\begin{tabular}{|c|c|c|c|}
\hline Phases & Building 2 & Building 3 & Building 1 \\
\hline Floor 2 & $2018-12-03$ & $2019-01-14$ & $2019-03-04$ \\
\hline Floor 3 & $2018-12-10$ & $2019-01-21$ & $2019-03-11$ \\
\hline Floor 4 & $2018-12-17$ & $2019-02-04$ & $2019-03-18$ \\
\hline Floor 5 & $2019-01-07$ & $2019-02-11$ & $2019-04-01$ \\
\hline $\begin{array}{c}\text { Floor 6 } \\
\text { Floor 7 }\end{array}$ & $2019-01-14$ & $2019-02-18$ & $2019-04-08$ \\
\hline $\begin{array}{c}\text { Roof } \\
\text { on }\end{array}$ & $2019-03-04$ & $2019-03-18$ & $2019-05-21$ \\
\hline $\begin{array}{c}\text { The heat } \\
\text { on }\end{array}$ & $2019-02-18$ & $2019-03-25$ & $2019-05-13$ \\
\hline
\end{tabular}

\subsection{Field measurements during frame construction}

\subsubsection{Measurement procedure}

Instantaneous moisture content measurements have been conducted and have occurred with intervals usually from three weeks to a month during construction of CLT structures. Measurement points were placed on horizontal surfaces, next to horizontal surfaces or on vertical surfaces (both interior walls and externally on external walls) also exposed to splashing water from horizontal surfaces, primarily on surfaces where water can pool or where drying opportunities are limited. These measurement points were selected to be well spread out on each floor, see Figure 9, to represent large parts of the buildings, based on indications or assumptions that they have also been exposed to precipitation or simply as random samples. Reference points for measurements have also been select at points not exposed to precipitation or having possible exposure to insignificant moisture amounts.

Moisture measurements were conducted using resistance measurements, Protimeter Timbermaster, together with hammer electrodes with insulated electrodes/steel pins at depths of $0,10,20,30,40,60$ $\mathrm{mm}$ from the top of the floor structure, in timber, in between timber in connections gap and in CLT panel joints, and near edges and end grains. This project has shown that measurements in connection gaps are equivalent to something between measuring surface moisture content [3] and moisture content in timber [50], depending on the width of the connection gap between timber. These measurements have used the indicated methods with certain deviations. In part, reported measurement values are based on single measurements instead of the average value of three measurements.

The instrument was adjusted appropriately for spruce wood. Temperature compensation did occur. Measurement uncertainty is estimated at $\pm 1.5 \%$ within the range $8-25 \%$ moisture content. Values below $8 \%$ moisture content were reported as $8 \%$ and values above $25 \%$ were reported as $25 \%$ moisture content.

Material was sampled using either hammer and chisel, see Figure 8, or a core drill to reach deeper into connection gaps, see Figure 9, or panel joints. Measurements of the top sides of floor structures under the sound and vibration pads were done diagonally downward with long insulated steel pins. Since the outer-most layer of the walls had a thickness of $20 \mathrm{~mm}$, both layers were often measured. The samples were taken in the field and were examined in the laboratory under stereo-microscope at 10 to 40 times magnification. To quantify growth, a preparation from the material surface is made, which is studied at magnification of up to 400 times. The preparation is made by scraping part of the surface with a sharp preparation nail or by taking a tape impression of the surface. These are then placed in a drop of lactic acid with cotton blue or alternatively a drop of potassium hydroxide solution on a microscope slide and then covered with a cover glass. The microbiological analyses are based on a defined method [51] and the analysis results are provided in a four-point scale: no growth, limited growth, moderate growth or extensive growth.

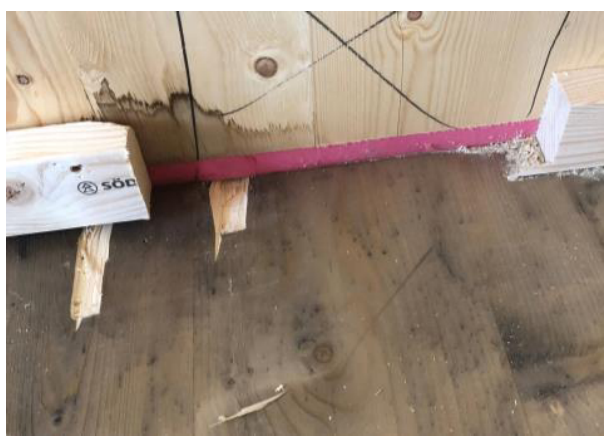

Fig. 8. Sample taken from the top side of the floor structure (CLT) under the sound and vibration pads and inner walls (CLT). The surfaces have been stained primarily by discoloured water. 


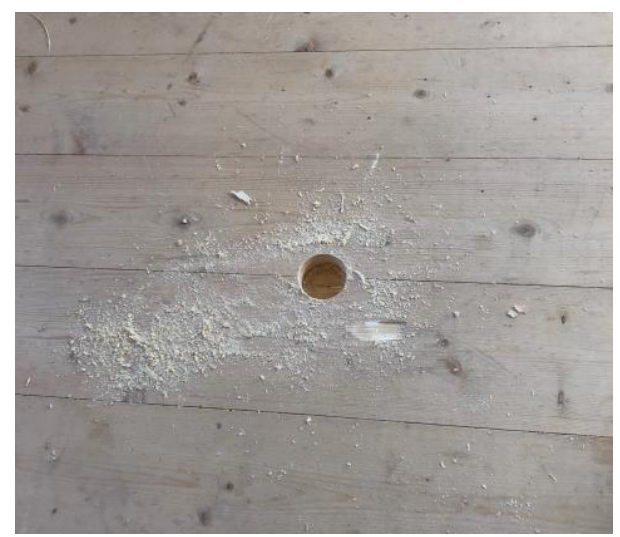

Fig. 9. Sample taken with a core drill in the connection gap between two timbers from the top of the floor structure (CLT).

\subsubsection{Results}

The moisture content measurements for all case studies showed that of 300 surface measurement points at $0 \mathrm{~mm}$ measurement depth, about one quarter had a moisture content of $19 \%$ or more. One of the locations with the largest percentage of elevated or high moisture content was in the bottom of the connection gap between timber in the top layer where about half of the measurement points had a $19 \%$ moisture content or higher.

The case study in west Sweden had 51 of 66 samples with microbial growth, the equivalent of 77 percent of measurement points. There was moderate to extensive growth at 58 percent of measurement points. At the case study in central Sweden, a third of 135 sample points had microbial growth. A fifth had moderate to extensive growth. The highest percentage with growth came from the top of the floor structure under the sound and vibration pads with 63 percent and half had moderate to extensive growth. In the connection gaps between timber in the floor structure in the upper most CLT layer, about half of the samples showed growth with 16 percent having moderate to extensive growth. At moisture content measurements in the middle of timber or in the second layer, relatively few had elevated moisture content. It seems that water does not easily absorb into the perpendicular fibres or through glued layers. Growth was found at several locations, see for example Figure 10 , on most of the floor structures, which indicates that it is significant.

In locations with mould growth, the moisture content varied from low to high moisture content depending on whether there was ongoing wetting, if it was still moist or if the moisture had dried, at the time of sampling. There were also measurement points with ongoing wetting which had not yet received mould growth. No growth was detected at locations not exposed to water.

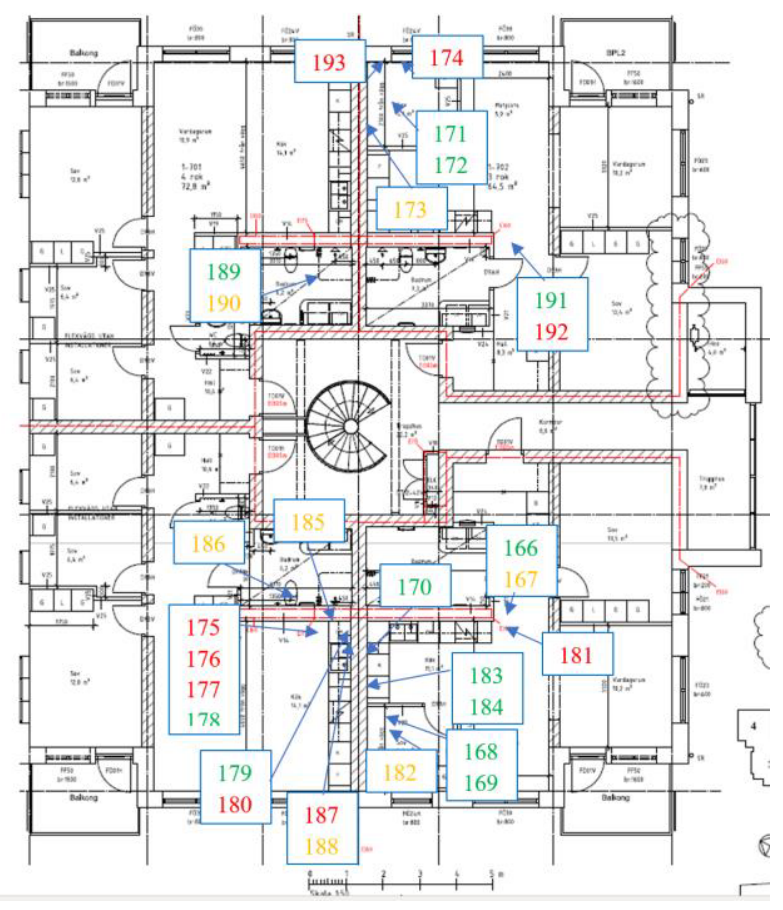

Fig. 10. Measurement point number and locations for one of the floor structures and building in central Sweden and the results. Green indicates had no growth, orange had limited growth and red had moderate or extensive growth.

\section{Conclusions}

Of a total of 200 analysed measurement points, half had some growth and about a third had moderate or extensive growth. Based on this study's results, it seems difficult or impossible to avoid the emergence of microbial growth during construction with CLT without weather protection. As such, the building regulations [1] and [2], could not be met. Thereafter, significant remediation work was to have been performed at all four case studies, but the results of this remediation do fall with this study's focus.

The mould growth is caused by exposure of the CLT to precipitation in the form of free water. No growth was detected at locations not exposed to water. This is as was expected since the mould risk simulations did not show any risk for growth when no water exposure occurred.

Mould growth is often invisible and cannot be detected with the naked eye. Detection requires microbiological analysis. There seems to be a general ignorance both nationally and internationally of how to detect microbial growth on CLT since it is rarely included in practical studies.

There appear to be no moisture safety assembly methods or solutions for CLT construction without weather protection or declaration of the critical moisture conditions for CLT products. As a result, it is recommended that weather protection, preferably complete weather protection, be used. 


\section{Future research needs}

More knowledge is needed about critical moisture conditions for mould growth on CLT and possibilities of remediation of CLT due to mould infestation.

The support from SBUF (the Swedish construction industry's organization for research and development) is gratefully acknowledged.

\section{References}

1. Boverket, Building Regulations, BFS 2011:6. 2017, The Swedish National Board of Housing, Building and Planning: Karlskrona, Sweden.

2. Svensk-Byggtjänst, AMA Hus 18, in HSD Konstruktioner av längdformvaror av trä $i$ hus. 2018, Svensk Byggtjänst: Stockholm.

3. Esping, B., J.-G. Salin, and P. Brander, Fukt $i$ trä för byggindustrin. 2005, Stockholm: SP Sveriges Provnings- och Forskningsinstitut.

4. Olsson, L., Moisture Conditions in Exterior Wooden Walls and Timber During Production and Use, in Chalmers, Civil and Environmental Engineering, Gothenburg, Sweden. 2014, Chalmers University of Technology: Gothenburg, Sweden. p. 101.

5. Axelsson, K., et al., Väderskyddad produktion Möjligheter och erfarenheter, 11259. 2004, FoUVäst: Göteborg.

6. Larsson, B. and L. Söderlind, Väderskyddad produktionsmiljö- Framtidens byggande. 2006, FoUVäst: Göteborg.

7. Brycke, E. and B. Martinsson, Väderskydd - En lathund för entreprenören, ID:13499. 2018, SBUF Svenska Byggbranschens utvecklingsfond: Göteborg.

8. Gustafsson, A., KL-trähandbok, Fakta och projektering av KL-träkonstruktioner. 2017, Stockholm: Svenskt trä. 186.

9. Olsson, L. and K. Mjörnell, Väderskyddat byggande eller omfattande fukt- och mögelkontroll av fuktexponerat virke, konstruktioner och KL-trä? Bygg \& Teknik, 2017. Nr 5.

10. Finch, G., High-Rise Wood Building Enclosures. ASHRAE, 2016.

11. Sedlbauer, K., Prediction of Mould Growth by Hygrothermal Calculation. 2001, FraunhoferInstitute for Building Physics: Holzkirchen.

12. Viitanen, H., Critical condtions for the mould growth in concrete and in other materials contacted with concrete - durability of concrete against mould growth (VTT W6). 2004, VTT Technical Research Centre of Finland: Espoo, Finland. p. 25.

13. Johansson, P., et al., Kritiskt fukttillstånd för mikrobiell tillväxt på byggmaterial Kunskapssammanfattning (SP Rapport 2005:11). 2005, SP Sveriges Provnings- och Forskningsinstitut: Borås.

14. Nevander, L.-E. and B. Elmarsson, eds. Fukthandboken - Praktik och teori "Moisture design manual" 2nd ed. 1994, Svensk Byggtjänst: Stockholm. 538.

15. Olsson, L. and K. Mjörnell. Laboratory investigation of sills and studs exposed to rain. in International Building Physics Conference (IBPC). 2012. Kyoto, Japan.

16. Johansson, P., A. Ekstrand-Tobin, and G. Bok, An innovative method for evaluating the critical moisture level for mould growth on building materials. Building \& Environment 65, 2014. 81(2 July 2014): p. 6.

17. Schmidt, E., L., et al., HOW MONITORING CLT BUILDINGS CAN REMOVE MARKET BARRIERS AND SUPPORT DESIGNERS IN NORTH AMERICA: AN INTRODUCTION TO PRELIMINARY ENVIRONMENTAL STUDIES, in CLEM+CIMAD 2017, II Ibero-American Congress on Construction Timber. 2017, National University of Northwestern Buenos Aires: Buenos Aires, Argentina.

18. Singh, T., D. Page, and I. Simpson, Manufactured structural timber building materials and their durability. Construction structural timber building materials and their durability, 2019. 217: p. p.84-92.

19. Glass, S., et al., CLT hanbook, Cross- Laminated Timber (Chapter 10), U.S. Edition, ed. E. Karacabeyli and B. Douglas. 2013, Pointe-Claire, Canada: FPInnovations.

20. McClung, R., et al., Hygrothermal performance of cross-laminated timber wall assemblies with built-in moisture: field measurements and simulations. Building and Environment, 2014. 71: p. p.95-110.

21. Wang, L. and H. Ge, Hygrothermal performance of cross-laminated timber wall assemblies: A stochastic approach. Building and Environment, 2016. 97: p. 14.

22. Kukk, V., et al., Impact of cracks to the hygrothermal properties of CLT water vapour resistance and air permeability, in 11th Nordic Symposium on Building Physics, NSB2017, 11-14 June 2017, , S. Geving and B. Time, Editors. 2017, Energy Procedia: Trondheim, Norway. p. 5.

23. Dietsch, P., et al., Monitoring building climate and timber moisture gradient in large-span timber structures. Journal of Civil Structural Health Monitoring, 2014. 5: p. 12.

24. Espinoza, O., et al., Cross-Laminated Timber: Status and Research Needs in Europe. BioResources, 2016.

25. Lepage, R., Moisture Response of Wall Assemblies of Cross-Laminated Timber Construction in Cold Canadian Climates. 2012, University of Waterloo: Waterloo, Ontario, Canada.

26. Liisma, E., et al., A case study on construction of CLT building without preliminary roof, in Forum Wood Building Baltic. 2019: Tallinn, Estonia.

27. Mjörnell, K., Olsson, L., Moisture Safety of Wooden Buildings- Design, Construction and Operation. Journal of sustainable architecture and civil engineering, 2019. 24, nr 1(1).

28. Nairn, J., Cross laminated timber properties including effects of non-glued edges and additional cracks. European Journal of Wood and Wood Products, 2017. 75: p. 10.

29. Scotta, R., et al., On the anchoring of timber walls to foundations: available strategies to prevent wood deterioration and on-site installation problems, in XIV International Conference on Building Pathology and Construction Repair-CINPAR 2018. 2018, Procedia Structural Integrity.

30. Nore, K., J. Mattsson, and M. Austigard, Cross Laminated Timber vs. timber frame walls in water damage - comparing drying and mould growth, in 10th Nordic Symposium on Building Physics, 15-19 June. 2014: Lund.

31. Srisgantharajah, J. and S. Ullah, En studie av fuktinnhold $i$ massivtre - Oppfuktings- og uttørkingsprosessen, A study of water content in 
cross- laminated timber - The wetting- and drying process., in Fakultet for miljøvitenskap og teknologi Institutt for matematiske realfag og teknologi. 2015, Norges miljø- og biovitenskapelige universitet.: Ås, Norway.

32. Kordziel, S., et al., MOISTURE MONITORING AND MODELING OF MASS TIMBER BUILDING SYSTEMS, in Wolrd Conference on Timber Engineering, August 20-23. 2018: Seoul, Republic Korea.

33. Lepage, R., J. Higgins, and G. Finch, Moisture Uptake Testing for CLT Floor Panels in a Tall Wood Building in Vancouver, in 15th Canadian Conference on Building Science and Technology. 2017: Vancouver, Canada.

34. Leyder, C., E. Chatzi, and A. Frangi, Structural health monitoring of an innovative timber building, in International Conference on Performance-based and Life-cycle Structural Engineering. 2015.

35. Mustapha, G., K. Khondoker, and J. Higgins, MOISTURE PERFORMANCE AND VERTICAL MOVEMENT MONITORING OF PREFABRICATED CROSS LAMINATE TIMBER FEATURED CASE STUDY: UBC TALLWOOD HOUSE, in 15th Canadian Conference on Building Science and Technology. 2017: Vancouver, Canada.

36. Wang, J.Y., et al., DURABILITY OF MASS TIMBER STRUCTURES: A REVIEW OF THE BIOLOGICAL RISKS. Wood and Fiber Science, 2018. 50: p. pp.110-127.

37.

Wang, J., WETTING AND DRYING PERFORMANCE OF WOOD-BASED ASSEMBLIES RELATED TO ON-SITE MOISTURE MANAGEMENT, in WCTE 2016 World Conference on Timber Engineering, August 22-25. 2016: Vienna, Austria.

38. Zelinka, S.L., et al., Moisture monitoring throughout the construction and occupancy of mass timber buildings, in 1 st International Conference on New Horizons in Green Cicil Engineeirng (NHICE-01), 25-27 April. 2018: Victoria, BC, Canada.

39. CEN, EN 16351:2015, Timber structures - Cross laminated timber - Requirements. 2015, European Committee for Standardization: Brussels.

40. Brandner, R., Production and Technology of Cross Laminated Timber (CLT): State-of-the-art Report, in Focus Solid Timber Solutions - European Conference on Cross Laminated Timber (CLT). 2013: Graz, Austria.

41. Alsayegh, G., et al., Preliminary Characterization of Physical Properties of Cross-Laminated-Timber (CLT) Panels for Hygrothermal Modelling. ASTM International, 2013. 2(1).

42. Matzinger, I. and I. Teibinger, Construction with Cross-Laminated Timber in Multi-Storey Buildings Focus on Building Physica- Guidelines. 2013, Vienna, Austria: Holzforschung Austria. 145.

43. Thivierge, C., Building with CLT Panels Durability Considerations, in Wood Design \& Building - Winter 2011-12. 2012. p. 4.

44. Öberg, J. and E. Wiege, Fuktrisker på KL-trä som utsätts för yttre klimat under produktion-fokus på mögel och uppfuktning, in Byggteknik och Design. 2018, KTH, Kungliga Tekniska Högskolan: Stockholm.

45. Dimstrand, D. and F. Jansson, KL-trä som stommaterial, in Fakulteten för hälsa, natur- och teknikvetenskap. 2018, Karlstads Universitet: Karlstad.
46. Gamboa, A.G., Water and Moisture in CLT. 2017, Wood Science and Engineering: Luleå.

47. Gamboa, A.G., Effects of water and moisture in CLT and how todry it. 2018, Wood Science and Engineeering: Luleå.

48. SMHI. Open Data. 2019 [cited 2019 August]; Available from: https://www.smhi.se/data.

49. Thelandersson, $\mathrm{S}$. and T. Isaksson, Mould resistance design (MRD) model for evaluation of microbial growth under varying climate conditions. . Building \& Environment 65, 2013.

50. SIS, SS-EN 13183-2, Moisture content of a piece of sawn timber- Part 2: Estimation by electrical resistance method. 2003, Swedish Standards Institute: Stockholm.

51. Hallenberg, N. and E. Gilert, Betingelser för mögelpåväxt på trä - Klimatkammarstudier (SP rapport 1988:57). 1988, Statens Provningsanstalt: Borås. 